\title{
Combined influence of diabetes mellitus and obesity on left ventricle remodeling in hypertensive patients
}

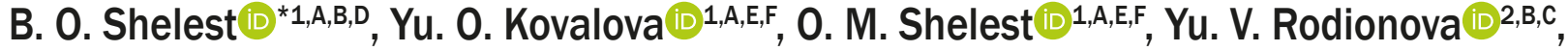 \\ Ya. V. Hilova $\mathbb{1}^{2, B, D}$
}

${ }^{1}$ Kharkiv National Medical University, Ukraine, ${ }^{2}$ Government Institution “L. T. Malaya Therapy National Institute of the National Academy of Medical Sciences of Ukraine", Kharkiv

A - research concept and design; B - collection and/or assembly of data; C - data analysis and interpretation; D - writing the article; $\mathrm{E}$ - critical revision of the article; $\mathrm{F}$ - final approval of the article

Key words: essential

hypertension, left ventricular remodeling, diabetes mellitus, obesity, myocardial hypertrophy.

Zaporozhye medical journa 2021; 23 (1), 46-51

*E-mail: Shelestb@ua.fm
The aim of the study was to evaluate the effect of type 2 diabetes mellitus (T2DM) and obesity influence on the left ventricular (LV) remodeling peculiarities in hypertensive patients.

Materials and methods. In total, 327 patients, aged 38-74 years, were comprehensively examined. The enrolled patients were divided into 4 groups in dependence of the presence of associated disease: the $1^{\text {st }}$ group $-n=87$ hypertensive patients with T2DM combined with obesity, the $2^{\text {nd }}$ group $-n=71$ hypertensive patient with T2DM and the $3^{\text {rd }}$ group $-n=65$ hypertensive patients with obesity; the comparison group consisted of 74 patients with essential hypertension (EH) but without obesity or diabetes.

Echocardiography was performed according to the standard method of $\mathrm{H}$. Feigenbaum to estimate the LV parameters. HbA1c was determined by turbidimetric method. Serum glucose levels were determined by ELISA.

Results. When comparing the three patient groups with those who had only $\mathrm{EH}$, the most significant influence was found in combined influence of T2DM and obesity on the development of unfavorable type of LV remodeling with values of $X^{2}=29.371$ and Pearson's contingency coefficient $(C)-0.393(P<0.05)$. The presence of concomitant T2DM without obesity had a significant moderate relationship with the development of unfavorable LV geometry, $X^{2}=11.029$ and $C-0.266(P<0.05)$, which indicates a much smaller impact on the process compared to the polymorbid effect of T2DM with obesity. Comparison of patients with a combination of EH and obesity with those who had only EH did not show a significant effect of concomitant obesity on the development of unfavorable types of LV geometry with values of $X^{2}$ and C: 0.529 and 0.062 , respectively $(\mathrm{P}>0.05)$.

Conclusions. Essential hypertension with type 2 diabetes mellitus and obesity polymorbidity, but not in combination with type 2 diabetes mellitus or obesity alone, has the most significant association with hypertrophic types of LV remodeling. The coexistence of type 2 diabetes mellitus and obesity in hypertensive patients leads to the development of predominantly LV concentric hypertrophy.
Киючові слова: гіпертонічна хвороба, ремоделювання мівого шлуночка, цукровий діабет 2 типу, ожиріння, гіпертрофія міокарда.

Запорізький медичний журнал 2021. T. 23, № 1(124) C. $46-51$

\section{Поєднаний вплив цукрового діабету 2 типу та ожиріння на ремоделювання Аівого шлуночка в пацієнтів із гіпертонічною хворобою}

\section{Б. О. Шелест, Ю. О. Ковальова, О. М. Шелест, Ю. В. Родіонова, Я. В. Гільова}

Мета роботи - оцінити вплив цукрового діабету (ЦД) 2 типу та ожиріння на особливості ремоделювання лівого шлуночка в пацієнтів із гіпертонічною хворобою (ГХ).

Матеріали та методи. Обстежили 327 пацієнтів віком 38-74 роки. Обстежених поділили на 4 групи залежно від наявності супутнього захворювання: 1 група - 87 пацієнтів із гіпертонічною хворобою, ЦД 2 типу в поєднанні 3 ожирінням; 2 група 71 хворий на гіпертонічну хворобу та цукровий діабет 2 типу; 3 група - 65 осіб із гіпертонічною хворобою та ожирінням; група порівняння -74 пацієнтів із ГХ без ожиріння та ЦД 2 типу.

Параметри лівого шлуночка (ЛШ) оцінювали за допомогою ехокардіографії за стандартною методикою Фейгенбаума. $\mathrm{HbA1c}$ визначали турбідиметричним методом, рівні глюкози в сироватці крові - імуноферментним.

Результати. Порівнюючи пацієнтів із трьох груп із хворими, які мали ізольований варіант ГХ, найбільший вплив на розвиток несприятливого типу ремоделювання ЛШ зі значеннями $X^{2}=29,371$ і коефіцієнта узгодженості Пірсона (C) - 0,393 $(p<0,05)$ виявили у разі одночасної наявності цукрового діабету 2 типу й ожиріння.

Наявність супутнього ЦД 2 типу без ожиріння мала значущий помірний зв'язок із розвитком несприятливої геометрії ЛШ, $\mathrm{X}^{2}=11,029$ і C - 0,266 ( $<$ < 0,05), що вказує на істотно менший вплив на процес порівняно з поліморбідним ефектом ЦД 2 типу та ожиріння. Порівняння пацієнтів з одночасним ГХ та ожирінням із тими, в кого наявна тільки ГХ, не показало значущий вплив супутнього ожиріння на розвиток несприятливих типів геометрії ЛШ зі значеннями $X^{2}$ і C 0,529 і 0,062 відповідно $(p>0,05)$.

Висновки. Гіпертонічна хвороба при поліморбідності з цукровим діабетом 2 типу й ожирінням, але не в поєднанні тільки з цукровим діабетом 2 типу або тільки з ожирінням має найбільш значущий зв'язок із гіпертрофічними типами ремоделювання лівого шлуночка. Одночасна наявність цукрового діабету 2 типу з ожирінням у гіпертензивних хворих призводить до розвитку здебільшого концентричної гіпертрофії лівого шлуночка. 


\section{Сочетанное влияние сахарного диабета 2 типа и ожирения на ремоделирование мевого желудочка у пациентов с гипертонической болезнью}

\section{Б. А. Шелест, Ю. А. Ковалёва, А. Н. Шелест, Ю. В. Родионова, Я. В. Гилёва}

Цель работы - оценить влияние сахарного диабета (СД) 2 типа и ожирения на особенности ремоделирования левого желудочка у пациентов с гипертонической болезнью (ГБ).

Материалы и методы. Обследовали 327 пациентов в возрасте 38-74 года. Пациентов поделили на 4 группы в зависимости от наличия сопутствующего заболевания: 1 группа - 87 больных гипертонической болезнью, сахарным диабетом 2 типа в сочетании с ожирением; 2 группа - 71 пациент с гипертонической болезнью и сахарным диабетом 2 типа; 3 группа - 65 больных гипертонической болезнью с ожирением; группа сравнения состояла из 74 пациентов с гипертонической болезнью без ожирения и без СД 2 типа.

Параметры левого желудочка (ЛЖ) оценивали с помощью эхокардиографии по стандартной методике Фейгенбаума. HbA1c определяли турбидиметрическим методом, а уровень глюкозы в сыворотке крови - иммуноферментным.

Результаты. При сравнении пациентов из трех групп с больными, имевшими изолированный вариант ГБ, наиболее значимое влияние на развитие неблагоприятного типа ремоделирования ЛЖ со значениями $X^{2}=29,371$ и коэффициента контингенции Пирсона $(C)-0,393$ ( $<$ < 0,05) обнаружено при одновременном влиянии сахарного диабета 2 типа и ожирения. Наличие сопутствующего СД 2 типа без ожирения имело значительную умеренную связь с развитием неблагоприятной геометрии ЛЖ, $X^{2}=11,029$ и C $-0,266(p<0,05)$, что указывает на гораздо меньшее влияние на процесс по сравнению с полиморбидным эффректом СД 2 типа и ожирения.

Сравнение пациентов с сочетанием ГБ и ожирения с теми, у кого была только ГБ, не показало значительного влияния сопутствующего ожирения на развитие неблагоприятных типов геометрии ЛЖ со значениями $\chi^{2}$ и C 0,529 и 0,062 соответственно $(p>0,05)$.

Выводы. Гипертоническая болезнь при полиморбидности с сахарным диабетом 2 типа и ожирением, но не в сочетании только с сахарным диабетом 2 типа или только с ожирением имеет наиболее значимую связь с гипертрофическими типами ремоделирования левого желудочка. Одновременное наличие сахарного диабета 2 типа с ожирением у гипертензивных больных приводит к развитию преимущественно концентрической гипертрофии левого желудочка.

In recent years, more and more attention is paid to the importance of heart remodeling in essential hypertension (EH) with concomitant pathology and complications [1-4].

Structural and functional changes of the myocardium, the geometry of the left ventricle (LV) and its remodeling significantly depend on the presence of risk factors that lead to the development of systolic and diastolic dysfunction [5].

The Framingham study proved that LV hypertrophy is an independent factor in cardiovascular morbidity and mortality and it plays an important role in myocardial dysfunction. Besides, the probability of developing cardiovascular pathology in obese people is $50 \%$ higher than in people with normal body weight.

In most cases, the degree of dilatation of heart chambers prevails in the presence of obesity. The size of the left atrium (LA) in obese patients is greater in comparison with the group of people with normal weight. The mechanisms leading to an increase in the LA size are identical to those that cause LF hypertrophy: an increase in body mass index (BMI), hypertension, volume overload and diastolic filling disorders. Framingham Heart Study showed a higher risk of atrial fibrillation among obese patients, which was due to an increase in the size of the LA.

A great attention should be paid to the features of myocardial LV remodeling among the other pathological processes affecting the state of the cardiovascular system in hypertensive patients with concomitant type 2 diabetes mellitus (T2DM) and obesity.

There are limited data about the level of combined influence of 2TDM with obesity on the LV hypertrophy in patients with $\mathrm{EH}$, whereas there is evidence of such impact of diabetes or obesity alone.

\section{Aim}

The aim of the study was to evaluate the influence of T2DM and obesity on the LV remodeling peculiarities in hypertensive patients.

\section{Materials and methods}

A total of 327 patients aged 38-74 years were comprehensively examined. The enrolled patients included 223 individuals with stage $\mathrm{II} \mathrm{EH}$, and they were divided into 3 groups depending on the presence of concomitant disease: the $1^{\text {st }}$ group $-\mathrm{n}=87$ hypertensive patients with T2DM combined with obesity, the $2^{\text {nd }}$ group $-n=71$ hypertensive patient with T2DM and the $3^{\text {rd }}$ group $-\mathrm{n}=65$ hypertensive patients with obesity; the comparison group consisted of 74 patients with hypertension only without obesity and diabetes.

All participants of the study signed an informed consent, and the Institute Ethical Committee of the participating centers approved the protocol. The study was conducted in accordance with the requirements of the Helsinki Declaration of the World Medical Association, Ukrainian Association statute of Bioethics and Standards GCP (1992), the requirements and norms of the ICH GCP (2002), standard provisions on ethics of the Ministry of Health of Ukraine No. 66 13.02.2006.

Anthropometric indicators were determined in all patients: height, body weight, waist circumference (WC), hip circumference $(\mathrm{HC})$ with subsequent calculation of body mass index by the formula: BMl = (body weight, $\mathrm{kg}$ )/ (height, $\mathrm{m}^{2}$ ) and the waist to hip ratio.

The mean age of patients in the main group was $59.07 \pm 12.15$ years. The comparison and experimental
Ключевые слова: гипертоническая болезнь, ремоделирование левого желудочка, сахарный диабет, ожирение, гипертрофия миокарда.

Запорожский медицинский журнал. 2021. T. 23, № 1(124) C. $46-51$ 
groups were age- and sex-matched (more than half of the patients were women). The average duration of $\mathrm{EH}$ in the main group was about 10 years, and in the comparison group, the duration of $\mathrm{EH}$ was approximately the same as in the main group. BMI in groups of patients was about $33 \mathrm{~kg} / \mathrm{m}^{2}$; body surface area and height of patients in all groups were statistically equal. All the patients of the main group were matched by functional classes $(\mathrm{FC})$ of heart failure $(\mathrm{HF})$.

Inclusion criteria into the study were the presence of $\mathrm{EH}$, T2DM, obesity, which were confirmed by various methods of examination. The clinical diagnosis was based on the patient complaints, anamnesis and physical examination. The diagnosis was confirmed using laboratory and instrumental methods in accordance with the recommendations of the European Society of Cardiology (2018).

The instrumental methods used were transthoracic echocardiography according to the standard method of H. Feigenbaum on an ultrasound machine "Philips HD11XE" (USA) in accordance with the generally accepted Echopulse method with an ultrasound frequency of $7.5 \mathrm{MHz}$. In the M-mode, the following parameters of the LV were determined: end-diastolic dimension (EDD) (cm), end-systolic dimension (ESD) (cm), LV posterior wall thickness (LVPWT) $(\mathrm{cm})$, interventricular septal thickness (IVST) (cm). End-diastolic volume (EDV) and end-systolic volume (ESV) (ml) of the LV were calculated by Simpson's method (1991), followed by LV ejection fraction (EF) (\%) measurement. LV myocardial mass (LVM) was calculated using the Devereux formula: $1.04 \times\left[(\text { IVST + LVPWT + EDD })^{3}\right]-[\text { EDD }]^{3}-$ 13.6. The calculation of the LV myocardial wall thickness index (iLVWT) was performed according to the formula: iLVWT = (LVPWT + IVST) / EDD.

Then, the LV myocardial mass index (iLVM) was calculated based on height of patients: iLVM $(\mathrm{g} / \mathrm{m})=\mathrm{LVM} /$ $\mathrm{P}$, where $\mathrm{P}$ - the height of patients $(\mathrm{m})$. In addition, the $L A$ $(\mathrm{cm})$ and aorta $(\mathrm{cm})$ size was determined.

Depending on iLVM and relative wall thickness (RWT), 4 types of LV remodeling in were defined: normal geometry (without changes), concentric remodeling (normal iLVM and increased RWT), eccentric hypertrophy (increased iLVM and normal RWT), concentric hypertrophy (increased iLVM and increased RWT) [4]. Than 2 groups were also formed: the first one was the hypertrophic type - eccentric and concentric hypertrophy, indicating an unfavorable, and the second one was non-hypertrophic type with normal geometry and concentric remodeling that was regarded as favorable. Such a categorization was done in accordance with contemporary international data [6-8].

T2DM diagnosis was established according to the WHO and IDF criteria with measuring fasting plasma glucose $-\geq 7.0 \mathrm{mmol} / \mathrm{l}(126 \mathrm{mg} / \mathrm{dl})$ and $2-\mathrm{h}$ venous plasma glucose after a $75 \mathrm{~g}$ oral glucose load $-\geq 11.1 \mathrm{mmol} / \mathrm{l}$ (200 $\mathrm{mg} / \mathrm{dl}), \mathrm{HbA} 1 \mathrm{c} \geq 6.5 \%$. HbA1c was determined in blood serum by turbidimetric method using the Liquidirect kit (Human $\mathrm{GmbH}$, Germany). Serum glucose levels were measured by enzyme-linked immunosorbent assay using DRG kits (USA).

The study was carried out in the Biochemical Department of the Central Research Laboratory of the Kharkiv National Medical University of the Ministry of Health of Ukraine on an enzyme-linked immunosorbent analyser "Labline-90" (Austria).
Obesity and its degree were diagnosed based on the WHO classification criteria. Body mass index was calculated by the formula BMI = (body weight, $\mathrm{kg}) /\left(\right.$ height, $\left.\mathrm{m}^{2}\right)$.

The exclusion criteria were: valvular heart disease; symptomatic (secondary) hypertension; concomitant endocrine, autoimmune, severe renal, oncological pathology; chronic obstructive pulmonary disease; exacerbation of chronic inflammatory processes or the presence of acute inflammatory diseases; cerebrovascular disorders; acute left or right ventricular failure; concomitant mental illness, alcoholism, drug addiction.

Statistical data processing was performed using Med Calc Version 19.3.1. (trial version) and SOFA Statistics 1.5.3 for Windows (open source AGPL3 license). For statistical processing of the results, parametric methods were used (the mean value $-M$, standard deviation $-S D$ or standard error of the mean value $-m$ ). The results were presented as $M \pm S D$, unless otherwise indicated. The quantitative Kolmogorov-Smirnov test was used to ascertain the normality of distribution hypothesis. Significance of differences between groups was determined using Student's t-test and the value of significance $-P$. A relationship between qualitative (attributive) features was measured via a $2 \times 2$ analysis using the four-field contingency table, with the $x^{2}$ (chi-square) and Pearson's contingency coefficient calculation.

\section{Results}

The baseline clinical characteristics of the enrolled patients are presented in Table 1. The patients from all groups were sex-, age-, smoking status-matched. Group 1 and 2 patients were matched by the severity of T2DM and group 1 and 3 - of obesity.

The types of LV remodeling were estimated during the examination of obese and non-obese patients with $\mathrm{EH}$ in the presence or absence of T2DM (Table 2).

The vast majority of patients with concentric hypertrophy $(70.12 \%)$ were found in the $1^{\text {st }}$ group (Table 2), fewer patients were with eccentric hypertrophy $(14.94 \%)$ and concentric remodeling (14.94\%) in equal proportions. Both concentric (36.92\%) and eccentric hypertrophy $(13.85 \%)$ were less frequent among obese hypertensive patients, while there were more individuals with concentric remodeling $(40.00 \%)$ and normal geometry (9.23\%). Eccentric type (16.90\%) was revealed less often in the patient group of EH and concomitant T2DM, concentric hypertrophy $(54.93 \%)$ was more often, concentric remodeling $(23.94 \%)$ and normal geometry occurred in only $4.23 \%$ of patients. The LV geometry in the $\mathrm{EH}$ group was as follows: $41.89 \%$ of patients with concentric and $2.70 \%$ - with eccentric hypertrophy and $27.03 \%$ - with concentric remodeling and $28.38 \%$ had normal geometry.

It is considered that concentric and eccentric types of LV remodeling (hypertrophic types) are rated among more prognostically unfavorable variants of heart geometry. The influence of comorbidity and polymorbidity on the development of adverse morpho-functional changes of the heart in hypertensive patients was evaluated. The distribution of patients with relatively favorable and unfavorable LV geometry variants was calculated. Thus, the unfavorable 
Table 1. Baseline characteristics of the examined subjects

\begin{tabular}{|c|c|c|c|c|}
\hline Parameter, units & EH + T2DM + Obesity & EH + T2DM & EH + Obesity & EH \\
\hline Age, years & $59.11 \pm 12.56$ & $58.59 \pm 11.82$ & $59.11 \pm 12.48$ & $58.03 \pm 13.21$ \\
\hline $\mathrm{BMI}, \mathrm{kg} / \mathrm{m}^{2}$ & $35.76 \pm 4.12$ & $27.76 \pm 4.83$ & $36.43 \pm 5.27$ & $24.96 \pm 5.76$ \\
\hline Sex, male, $\mathrm{n}(\%)$ & $37(43)$ & $29(41)$ & $26(40)$ & $32(43)$ \\
\hline $\mathrm{HbA1c}, \%$ & $7.12 \pm 1.56$ & $7.25 \pm 1.31$ & $5.32 \pm 1.23$ & $5.05 \pm 1.78$ \\
\hline $\mathrm{SBP}(\mathrm{mm} \mathrm{Hg})$ & $153.83 \pm 19.21$ & $155.51 \pm 18.37$ & $152.76 \pm 20.09$ & $154.90 \pm 19.15$ \\
\hline $\mathrm{DBP}(\mathrm{mm} \mathrm{Hg})$ & $94.89 \pm 11.54$ & $95.14 \pm 10.03$ & $94.35 \pm 11.01$ & $95.61 \pm 10.17$ \\
\hline Smoking, n (\%) & $17(20)$ & $15(21)$ & $13(20)$ & $16(22)$ \\
\hline
\end{tabular}

EH: essential hypertension; T2DM: type 2 diabetes mellitus; BMI: body mass index; SBP: systolic blood pressure; DBP: diastolic blood pressure.

Table 2. Distribution of patients in the groups (by the presence of comorbid or polymorbid pathology) depending on the type of heart remodeling

\begin{tabular}{|c|c|c|c|c|}
\hline Type of geometry & EH + T2DM + Obesity & EH + T2DM & EH + Obesity & EH \\
\hline Normal heart geometry, patients, n (\%) & $0(0)$ & $3(4.23)$ & $6(9.23)$ & $21(28.38)$ \\
\hline Concentric remodeling, patients, $n(\%)$ & $13(14.94)$ & $17(23.94)$ & $26(40.0)$ & $20(27.03)$ \\
\hline Concentric hypertrophy, patients, n (\%) & $61(70.12)$ & $39(54.93)$ & $24(36.92)$ & $31(41.89)$ \\
\hline Eccentric hypertrophy, patients, $n(\%)$ & $13(14.94)$ & $12(16.90)$ & $9(13.85)$ & $2(2.70)$ \\
\hline
\end{tabular}

EH: essential hypertension; T2DM: type 2 diabetes mellitus.

Table 3. The values of Pearson's $X^{2}$ criteria and contingency coefficients in the analysis of comorbidity or polymorbidity influence on the unfavorable variants of LV geometry development

\begin{tabular}{|l|l|l|l|l|l}
\hline Statistical criteria & $\begin{array}{l}\text { Group } 1 \text { in relation to } \\
\text { the comparison group }\end{array}$ & $\begin{array}{l}\text { Group 2 in relation to } \\
\text { the comparison group }\end{array}$ & $\begin{array}{l}\text { Group 3 in relation to } \\
\text { the comparison group }\end{array}$ & $\begin{array}{l}\text { Group 1 compared to } \\
\text { group 2 }\end{array}$ & $\begin{array}{l}\text { Group 1 compared to } \\
\text { group 3 }\end{array}$ \\
\hline$X^{2}$ & $29.371(P<0.05)$ & $11.029(P<0.05)$ & $0.529(P>0.05)$ & $4.139(P<0.05)$ \\
\hline Pearson's contingency coefficient & 0.393 & 0.266 & 0.062 & $20.988(P<0.01)$ \\
\hline
\end{tabular}

(hypertrophic) type (concentric plus eccentric hypertrophy) was the most common in the group with polymorbidity $85.06 \%$ of patients, and it was the lowest type in the group with only $\mathrm{EH}-44.59 \%$, while in the concomitant obesity subgroup $-50.77 \%$ and in the subgroup with combined EH and T2DM $-71.83 \%$.

The analysis of the certain comorbidity influences (T2DM, obesity or their coexistence) on the development of unfavorable types of LV remodeling using Pearson's $X^{2}$ criteria and contingency coefficient to compare the patients from three groups with $\mathrm{EH}$ alone, revealed the most significant impact of the T2DM and obesity combination $\left(X^{2}=29.371\right.$ and Pearson's contingency coefficient 0.393) (Table 3).

The result suggested a significant strong association between polymorbidity and the formation of such LV remodeling types as concentric and eccentric hypertrophy. The presence of concomitant T2DM without obesity had a significant moderate correlation with the development of unfavorable LV geometry, the value of $X^{2}$ and Pearson's contingency coefficient were as follows: 11.029 and 0.266 , respectively, indicating a much lesser impact on the process compared to the polymorbid effect of T2DM coexisting with obesity. Comparison of patients with the combination of $\mathrm{EH}$ and obesity to those who had only $\mathrm{EH}$, did not show a significant effect of concomitant obesity on the unfavorable types of LV geometry development with values of $X^{2}$ and Pearson contingency coefficient 0.529 and 0.062 , respectively. However, when comparing group 1 (polymorbid) to group 2 (with concomitant T2DM), the value of $X^{2}=4.139$ $(P<0.05)$ and Pearson's contingency coefficient of 0.160 were found to indicate a less significant effect of T2DM alone on the development of left ventricular hypertrophy $(\mathrm{LVH})$ than the combined effect of type $2 \mathrm{DM}$ and obesity. A comparison between groups 1 and 3 (with obesity alone) revealed a relationship of medium strength between polymorbidity and the development of unfavorable LV geometry with values of $X^{2}=20.988(P<0.001)$ and Pearson's contingency coefficient of 0.348 compared to the influence of comorbid obesity.

\section{Discussion}

It is known that long-term EH leads to the development of $\mathrm{LV}$ remodeling, which is characterized by changes in its geometric model. LV remodeling is considered as a compensatory response to increased LV load, which includes changes in volume and iLVM. Changes in the LV normal geometry worsen the disease prognosis provoking ischemic injuries [5].

Structural changes in the heart in obese patients can be divided into the following main components: LV hypertrophy, changes in the cardiac tissue structure, changes in the size of the right ventricle and LA [9]. Some researchers have found an independent association between obesity and LV hypertrophy [10]. Some scientists hold that an increase in LV mass indexing to body surface area accounted for the effects of obesity is not pathological. Previous studies have shown that obesity causes dilatation of the heart chambers [11].

It has been demonstrated that higher LV wall thickness $>1 \mathrm{~cm}$ increases the risk of fatal complications. The risk of adverse coronary events is increased in the case of greater iLVM. In addition, the presence of LVH signs increases by a third 5 -year mortality rates in men and by a quarter - in women. The relative risk of sudden cardiac death was found to be associated with an increase in iLVM detected by echocardiography. Meanwhile, normalization of blood pressure and reducing the degree of hypertrophy lower the risk of sudden cardiac death [12-14]. 
The LIFE study and its additional analysis demonstrated the results according to which the presence of $\mathrm{LVH}$ and left bundle branch block signs on ECG increases the risk of cardiovascular death by 1,6 times, sudden cardiac death - by 3,4 times and hospital admission rate for heart failure - by 1.7 times [15].

The data from the Jackson Heart Study (USA) suggest that cardiovascular complications were statistically more common in patients with inappropriate LVM $\left(\geq 45 \mathrm{~g} / \mathrm{m}^{2.7}\right.$ in women and $\geq 49 \mathrm{~g} / \mathrm{m}^{2.7}$ in men) [16]. The PAMELA study indicates 4 and 5 times increased risk of cardiovascular events and death in the presence of LVH signs on ECG [17].

Our study was aimed at attempting to use an easy statistical method as table $2 \times 2$ with $x^{2}$ and Pearson's contingency coefficient identification to find out the combined influence of diabetes and obesity on the development of LV remodeling in hypertensive patients and correlation degree, but apart from that, the study examined the influence of T2DM or obesity alone.

The study of Tan Li et al. was similar to the present one in some aspects, but it was investigation of hypertension with diabetes mellitus alone, without obesity [18]. Herewith, the authors concluded that hypertensive patients with diabetes mellitus had increased risk for LVH and concentric hypertrophy in the total and female patients separately, but on the other hand, they did not find an association of $\mathrm{EH}$ and diabetes mellitus comorbidity with LVH and abnormal geometrical patterns in men. In our study, there were no differences in the development of LV remodeling between male and female populations.

The data from another study carried out by Kirstie A. de Jong et al. [19] showed that metabolically non-healthy obese, T2DM and obese patients with T2DM can develop LV hypertrophy regardless of $\mathrm{EH}$. These findings are consistent with our, but that study was focused on patients without hypertension.

One of the main findings of the present study is that patients with polimorbidity should be strictly followed up, as it can prevent the process of LV remodeling and improve outcomes [20,21].

Our study found that there were the most overt structural and functional changes in the myocardium in the patient group of EH combined with T2DM and obesity. Decreased LV functional capacity is an important indicator of myocardial compensatory reserve depletion and significantly affects the severity of clinical manifestations in hypertensive patients with T2DM and obesity.

It should be noted that our study had some limitations being limited in sample size of enrolled patients and cross-sectional in character. T2DM patients had only mild and moderate course, we did not analyze those with severe course. Consequently, further investigation on this problem with larger sample size and longer follow-up period is needed to find out the influence of comorbidity on the development of $L V$ remodeling.

\section{Conclusions}

1. Primarily, polymorbidity of essential hypertension with type 2 diabetes and obesity, but not in combination with type 2 diabetes or obesity alone, significantly influences the parameters of left ventricle geometry.
2. Thus, the results obtained in the work indicate that the coexistence of type 2 diabetes mellitus with obesity in hypertensive patients leads to the development of LV concentric hypertrophy predominantly, while the presence of type 2 diabetes mellitus alone in hypertensive patients results in this type of remodeling one fifth less often. Obesity in hypertension is one third less significant in formation of concentric hypertrophy compared to polymorbidity influence.

The perspective for further scientific research lie in the field of the study on pathogenetic features of stage I, II, III EH associated with concomitant diseases, especially T2DM and obesity.

Conflicts of interest: authors have no conflict of interest to declare. Конфлікт інтересів: віАсутній.

Надійшла Ао реАакції / Received: 19.06.2020

Після Аоопрацювання / Revised: 08.09.2020

Прийнято АО Аруку / Accepted: 12.10.2020

\section{Information about authors:}

Shelest B. O., MD, PhD, Associate Professor of the Department of Internal and Occupational Diseases, Kharkiv National Medical University, Ukraine.

ORCID ID: 0000-0001-5528-8302

Kovalova Yu. O., MD, PhD, Associate Professor of the Department of Internal Medicine No. 2 and Clinical Immunology and Allergology named after Academician L. T. Malaya, Kharkiv National Medical University, Ukraine.

ORCID ID: 0000-0002-6463-9861

Shelest O. M., MD, PhD, DSc, Professor of the Department of Internal Medicine No. 2 and Clinical Immunology and Allergology named after Academician L. T. Malaya, Kharkiv National Medical University, Ukraine.

ORCID ID: 0000-0002-9402-7209

Rodionova Yu. V., MD, PhD, Researcher, Department of Prevention and Treatment of Emergencies, Government Institution

"L. T. Malaya Therapy National Institute of the National Academy of Medical Sciences of Ukraine", Kharkiv.

ORCID ID: 0000-0001-8438-9401

Hilova Ya. V., MD, PhD, Researcher, Department of Prevention and Treatment of Emergencies, Government Institution “L. T. Malaya Therapy National Institute of the National Academy of Medical Sciences of Ukraine", Kharkiv. ORCID ID: 0000-0002-4545-3009

\section{Відомості про авторів:}

Шелест Б. О., канА. меА. наук, Аоцент каф. внутрішніх та професійних хвороб, Харківський національний медичний університет, Україна.

Ковальова Ю. О., канА. меА. наук, Аоцент каф. внутрішньої меАицини № 2 і клінічної імунології та алергології імені академіка $\Lambda$. Т. Малої, Харківський національний медичний університет, Україна.

Шелест О.М., А-р. меА. наук, професор каф. внутрішньої медицини № 2 і клінічної імунології та алергології імені академіка $\Lambda$. Т. Малої, Харківський національний медичний університет, Україна.

Родіонова Ю. В., канд. меА. наук, науковий співробітник відАілу профілактики та лікування невідкладних станів,

АУ «Національний інститут терапії імені $\Lambda$. Т. Малої НАМН України", м. Харків, Україна.

Гільова Я. В., канА. меА. наук, науковий співробітник відаіл профілактики та лікування невідкладних станів.

АУ «Національний інститут терапії імені $\Lambda$. Т. Малої НАМН України", м. Харків, Україна.

Сведения об авторах:

Шелест Б. А., канА. меА. наук, Аоцент каф. внутренних и профессиональных болезней, Харьковский национальный медицинский университет, Украина. 
Ковалёва Ю. А., канА. меА. наук, доцент каф. внутренней медицины № 2 и клинической иммунологии и аммергологии имени академика $\Lambda$. Т. Малой, Харьковский национальный меАицинский университет, Украина.

Шелест А. Н., А-р меА. наук, профессор каф. внутренней меАицины № 2 и клинической иммунологии и аммергологии имени академика $\Lambda$. Т. Малой, Харьковский национальный медицинский университет, Украина.

Родионова Ю. В., канА. меА. наук, научный сотрудник отАела профилактики и лечения неотложных состояний, ГУ „Национальный институт терапии имени $\Lambda$. Т. Малой НАМН Украины", г. Харьков.

Гилёва Я. В., канА. меА. наук, научный сотрудник отАела профилактики и лечения неотложных состояний, ГУ «Национальный институт терапии имени $\wedge$. Т. Малой НАМН Украины", г. Харьков.

\section{References}

[1] Lancellotti, P., Galderisi, M., Edvardsen, T., Donal, E., Goliasch, G., Cardim, N., Magne, J., Laginha, S., Hagendorff, A., Haland, T. F., Aaberge, L., Martinez, C., Rapacciuolo, A., Santoro, C., llardi, F., Postolache, A., Dulgheru, R., Mateescu, A. D., Beladan, C. C., Deleanu, D., ... Popescu, B. A. (2017). Echo-Doppler estimation of left ventricular filling pressure: results of the multicentre EACVI Euro-Filling study. European Heart Journal - Cardiovascular Imaging, 18(9), 961-968. https://doi.org/10.1093/ehjici/jex067

[2] Andersen, O.S. Smiseth O.A. Dokainish, H. Abudiab, M. M. Schutt, R. C., Kumar, A., Sato, K., Harb, S., Gude, E., Remme, E. W., Andreassen, A. K., Ha, J. W., Xu, J., Klein, A. L., \& Nagueh, S. F. (2017). Estimating Left Ventricular Filling Pressure by Echocardiography. Journal of the American College of Cardiology, 69(15), 1937-1948. https://doi.org/10.1016/j.jacc.2017.01.058

[3] Sanchis, L., Andrea, R., Falces, C., Poyatos, S., Vidal, B., \& Sitges, M. (2018). Differential Clinical Implications of Current Recommendations for the Evaluation of Left Ventricular Diastolic Function by Echocardiography. Journal of the American Society of Echocardiography, 31(11), 1203-1208. https://doi.org/10.1016/i.echo.2018.08.011

[4] Cokkinos, D. V., \& Belogianneas, C. (2016). Left Ventricular Remodelling: A Problem in Search of Solutions. European Cardiology Review, 11(1), 29-35. https://doi.org/10.15420/ecr.2015:9:3

[5] Krukov, E. V., Orlov, F. A., \& Alatortseva, I. A. (2019). Klinicheskaya otsenka faktorov riska serdechno-sosudistykh oslozhnenii metodom matematicheskogo modelirovaniya u patsientov s raznymi geometricheskimi modelyami serdtsa [Clinical assessment of cardiovascular complication risk factors by a mathematic modeling method in patients with different geometric heart models]. Sovremennye problemy zdravookhraneniya i meditsinskoi statistiki, (3), 1-15. https://doi. org/10.24411/2312-2935-2019-10051 [in Russian]

[6] Yildiz, M., Oktay, A. A., Stewart, M. H., Milani, R. V., Ventura, H. O., \& Lavie, C. J. (2020). Left ventricular hypertrophy and hypertension. Progress in Cardiovascular Diseases, 63(1), 10-21. https://doi. org/10.1016/i.pcad.2019.11.009

[7] Verdecchia, P., Angeli, F., Mazzotta, G., Bartolini, C., Garofoli, M., Aita, A., Poltronieri, C., Pinzagli, M. G., Valecchi, F., Martone, S., Ramundo, E., Turturiello, D., \& Reboldi, G. (2017). Impact of Chamber Dilatation on the Prognostic Value of Left Ventricular Geometry in Hypertension. Journal of the American Heart Association, 6(6), Article e005948. https:/l doi.org/10.1161/JAHA.117.005948

[8] Paoletti, E., De Nicola, L., Gabbai, F. B., Chiodini, P., Ravera, M. Pieracci, L., Marre, S., Cassottana, P., Lucà, S., Vettoretti, S., Borrelli, S., Conte, G., \& Minutolo, R. (2016). Associations of Left Ventricular Hypertrophy and Geometry with Adverse Outcomes in Patients with CKD and Hypertension. Clinical journal of the American Society of Nephrology, 11(2), 271-279. https://doi.org/10.2215/CJN.06980615

[9] Cromwell, C. M., Aichele, K. R., Oakman, J. E., Neal, M. P., Lenzo, J. M., Perez, A. N., Bye, N. L., Santaniello, E. L., Hill, J. A., Evans, R. C., Thiele, K. A., Chavis, L. N., Getty, A. K., Wisdo, T. R., \& Feairheller, D. L. (2016). Carotid Artery IMT, Blood Pressure, and Cardiovascular Risk Factors in Males and Females. International Journal of Exercise Science, 9(4), 482-490.

[10] Polozova, E. I., \& Mamkina, N. N. (2017). Osobennosti strukturno-geometricheskoi perestroiki levogo zheludochka u bol'nykh s metabolicheskim sindromom i arterial'noi gipertenziei [Remodeling in left ventriculat structure and geometry in patients with metabolic syndrome and arterial hypertension]. Ul'yanovskii mediko-biologicheskii zhurnal, (4), 26-32. https://doi.org/10.23648/UMBJ.2017.28.8737 [in Russian].

[11] Shakhnovich, P. G., Zakharova, A. I., Cherkashin, D. V., Svistov, A. S., Shalenin, K. S., Tkachenko, K. N., Alanichev, A. E., Makiev, R. G., Kutelev, G. G., \& Efimov, S. V. (2015). Diastolicheskaya disfunktsiya miokarda: ekhokardiograficheskii fenomen ili vid serdechnoi nedostatochnosti? [Diastolic myocardium dysfunction: echocardiographic phenomenon or type of heart failure?]. Vestnik rossiiskoi voenno-meditsinskoi akademii, (3), 54-57. [in Russian]

[12] Tsao, C. W., Gona, P. N., Salton, C. J., Chuang, M. L., Levy, D., Manning. W. J., \& O'Donnell, C. J. (2015). Left Ventricular Structure and Risk of Cardiovascular Events: A Framingham Heart Study Cardiac Magnetic Resonance Study. Journal of the American Heart Association, 4(9), Article e002188. https://doi.org/10.1161/JAHA.115.002188

[13] Aljaroudi, W., Alraies, M. C., Halley, C., Rodriguez, L., Grimm, R. A., Thomas, J. D., \& Jaber, W. A. (2012). Impact of progression of diastolic dysfunction on mortality in patients with normal ejection fraction. Circulation, 125(6), 782-788. https://doi.org/10.1161/CIRCULATIONAHA.111.066423

[14] Soliman, E. Z., Ambrosius, W. T., Cushman, W. C., Zhang, Z. M., Bates, J. T., Neyra, J. A., Carson, T. Y., Tamariz, L., Ghazi, L., Cho, M. E., Shapiro, B. P., He, J., Fine, L. J., Lewis, C. E., \& SPRINT Research Study Group. (2017). Effect of Intensive Blood Pressure Lowering on Left Ventricular Hypertrophy in Patients With Hypertension: SPRINT (Systolic Blood Pressure Intervention Trial). Circulation, 136(5), 440450. https://doi.org/10.1161/CIRCULATIONAHA.117.02844

[15] Katsiki, N., Tsioufis, K., Ural, D., \& Volpe, M. (2018). Fifteen years of LIFE (Losartan Intervention for Endpoint Reduction in Hypertension)-Lessons learned for losartan: An "old dog playing good tricks". Journal of Clinical Hypertension, 20(8), 1153-1159. https://doi. org/10.1111/jch.13325

[16] Anstey, D. E., Tanner, R. M., Booth, J. N., 3rd, Bress, A. P., Diaz, K. M., Sims, M., Ogedegbe, G., Muntner, P., \& Abdalla, M. (2019). Inappropriate Left Ventricular Mass and Cardiovascular Disease Events and Mortality in Blacks: The Jackson Heart Study. Journal of the American Heart Association, 8(16), Article e011897. https://doi.org/10.1161/ JAHA.118.011897

[17] Cuspidi, C., Sala, C., Casati, A., Bombelli, M., Grassi, G., \& Mancia, G. (2017). Clinical and prognostic value of hypertensive cardiac damage in the PAMELA Study. Hypertension Research, 40(4), 329-335. https:// doi.org/10.1038/hr.2016.153

[18] Li, T., Chen, S., Guo, X., Yang, J., \& Sun, Y. (2017). Impact of hypertension with or without diabetes on left ventricular remodeling in rural Chinese population: a cross-sectional study. BMC Cardiovascular Disorders, 17(1), Article 206. https://doi.org/10.1186/s12872-017-0642-y

[19] De Jong, K. A., Czeczor, J. K., Sithara, S., McEwen, K., Lopaschuk, G. D., Appelbe, A., Cukier, K., Kotowicz, M., \& McGee, S. L. (2017). Obesity and type 2 diabetes have additive effects on left ventricular remodelling in normotensive patients-a cross sectional study. Cardiovascular Diabetology, 16(1), Article 21. https://doi.org/10.1186/s12933-017-0504-z

[20] Azevedo, P. S. Polegato, B. F., Minicucci, M. F. Paiva, S. A. \& Zornoff, L. A. (2016). Cardiac Remodeling: Concepts, Clinical Impact, Pathophysiological Mechanisms and Pharmacologic Treatment. Arquivos Brasileiros de Cardiologia, 106(1), 62-69. https://doi.org/10.5935/ abc. 20160005

[21] Roush, G. C., Abdelfattah, R., Song, S., Kostis, J. B., Ernst, M. E., \& Sica, D. A. (2018). Hydrochlorothiazide and alternative diuretics versus renin-angiotensin system inhibitors for the regression of left ventricular hypertrophy: a head-to-head meta-analysis. Journal of Hypertension, 36(6), 1247-1255. https://doi.org/10.1097/HJH.0000000000001691 